\title{
On the Development of Cross-Border E-Commerce and the Transformation of Foreign Trade Model
}

\author{
Pengyan Wang \\ Economics College, Sichuan University of Science \& Engineering, Zigong, China \\ Email: pengyanw@163.com
}

How to cite this paper: Wang, P.Y. (2018) On the Development of Cross-Border E-Commerce and the Transformation of Foreign Trade Model. Modern Economy, 9, 1665-1671.

https://doi.org/10.4236/me.2018.910105

Received: September 21, 2018

Accepted: October 22, 2018

Published: October 25, 2018

Copyright $\odot 2018$ by author and Scientific Research Publishing Inc. This work is licensed under the Creative Commons Attribution International License (CC BY 4.0).

http://creativecommons.org/licenses/by/4.0/

\section{(c) (i) Open Access}

\begin{abstract}
In recent years, the international economic development has been continuously sluggish. The market environment has been deteriorating, and the competition has become increasingly fierce. The development of small and medium-sized enterprises is restricted by factors such as capital, talents and market. With the development of Internet technology, the emergence of cross-border e-commerce has attracted the attention of Chinese government and enterprises. E-commerce has become a new mode of trade. On the one hand, it can solve the problem of insufficient enterprise resources; on the other hand, it can realize the rational allocation of enterprise resources. E-commerce is of great significance to the development of small and medium-sized enterprises oriented by foreign trade. It can help small and medium-sized enterprises effectively to solve problems in capital, talents and market, and help them develop and grow. The rapid development of e-commerce has given rise to a new form of international trade, namely cross-border e-commerce. Its development has a great influence on the development of traditional foreign trade. Based on the development status of cross-border e-commerce in China, this paper analyzes the influence of the development of cross-border e-commerce on China's foreign trade mode, and proposes foreign trade pattern transformation strategies in order to provide reference for the development of cross-border e-commerce and foreign trade in China.
\end{abstract}

\section{Keywords}

Cross-Border E-Commerce, Foreign Trade, Transformation, Models

\section{Introduction}

There are many kinds of e-commerce, and cross-border e-commerce is one of 
them. Cross-border e-commerce is an extension of e-commerce development. It mainly refers to that the transaction subjects of different countries and regions conduct business transactions with the help of e-commerce platforms, and transfer goods through cross-border logistics. There are three main modes of trade: B2B (Business to Business), B2C (Business to Consumer), C2C (Consumer to Consumer). Cross-border e-commerce not only shortens the distance between products from manufacturers to foreign consumers, but also has an impact on the value chain of foreign trade, trade market and its market subject, production mode and cost, which as a result changed the traditional modes of foreign trades. The development of cross-border e-commerce breaks down barriers between countries, promotes the development of trade without borders and affects the development of world economy. At the same time, it can help enterprises to establish diversified economic and trade relations, achieve rational allocation of resources on a global scale. For consumers, more information is available. They can buy quality products at reasonable prices and enjoy better service. From the perspective of China's development, the development of cross-border e-commerce has a great impact on the transformation and development of China's foreign trade [1]. This paper discusses the existing problems in cross-border e-commerce trade, analyzes the influence of the development of cross-border e-commerce on China's foreign trade mode, then proposes some foreign trade pattern transformation strategies.

\section{The Current Status and Problems of Cross-Border E-Commerce Development}

\subsection{Development Status of Cross-Border Trade E-Commerce in China}

Cross-border e-commerce started late in China, but it has come to a fierce and rapid development. The Chinese government is acutely aware of the huge impact of cross-border e-commerce on economic growth and corporate competitiveness. Since the early 1990s, a series of "golden" word projects, such as "golden bridge", "golden card" and "golden gate", have been implemented successively in important sectors of national economy and industries with relatively developed information foundation (Collectively referred to as the "three golden" projects), which opened the prelude that international trade domain in China uses the electronic commerce technology. The "SARS" in 2003 had a great impact on China's production and lifestyle. But at the same time, it provides an opportunity for the development of e-commerce in China. After that, as various industries and departments gradually realize the informatization work and various e-commerce network platforms rise, electronic commerce entered the stage of rapid development from 2005 in China. Affected by the global financial crisis, the appreciation of RMB and the continuous rise of labor costs in 2008, China's traditional foreign trade industry has been hit hard, with import and export growth falling significantly. Many small and medium-sized foreign trade enter- 
prises have closed down. By contrast, Due to the advantages of few intermediate links, low price and high profit margin, cross-border e-commerce presents a good development momentum. According to the statistics of Qianzhan website, there are over 5000 cross-border e-commerce platforms and over 200,000 enterprises in China [2].

According to website information of National Bureau of Statistics [3], China's cross-border e-commerce import and export volume was 0.8 trillion yuan in 2008, which accounted for 4.6 percent of the total import and export volume of that year. By 2011, China's cross-border e-commerce transactions reached 1.8 trillion yuan, accounting for 7.5 percent of the total imports and exports volume of the year. In 2013, China's total import and export value exceeded us $\$ 4$ trillion (about 25.83 trillion yuan) for the first time, among which the total import and export volume of cross-border e-commerce reached 3.1 trillion yuan, accounting for 12 percent of the total value.

\subsection{Problems in Cross-Border E-Commerce Trade}

\subsubsection{Regulation and Taxation Are Relatively Backward}

Cross-border e-commerce transactions are completed online. When goods are delivered through cross-border logistics, customs duties and other issues will be involved in the delivery process. The level of customs taxation directly affects the development of cross-border e-commerce. If taxes are high, merchants will raise the prices. In this way, compared with other domestic commodities, the competitive edge is weakened. In addition, with the in-depth development of e-commerce, the quantity of cross-border e-commerce goods is increasing, which has greatly increased customs workload. It is also common for individuals to carry prohibited items through customs, which makes customs work more difficult [4].

\subsubsection{Logistics Cost of Cross-Border E-Commerce Is High}

Compared with the traditional commercial activities, e-commerce has the advantages of abundant product varieties, strong selectivity, materiality and timely delivery. It also indicates that the development of e-commerce is more dependent on the logistics industry. At present, logistics has become an important factor restricting the development of e-commerce. Among cross-border e-commerce enterprises, air transportation is often selected, which has relatively high cost. It will charge higher transportation fees, which will also increase the cost of enterprises. From the perspective of current development, China's logistics system in cross-border e-commerce is still relatively lacking, which affects the healthy development of e-commerce.

\subsubsection{Security Issues with Payments}

Cross-border e-commerce transactions are mainly completed through online banking and other online payment platforms. And the development of Internet itself exists certain security risk. Enterprise information data and user login information are likely to be leaked. This is also an issue that needs to be addressed in the development of cross-border e-commerce [5]. 


\subsubsection{The Problem about Export Tax Rebate System}

Export tax rebate system is to refund taxes which have been paid in order to let domestic products enter international market without tax cost. In this way, the exporting products could compete with foreign products under the same condition. And as a result, it increases the volume of foreign exchange generated from exports. Generally, cross-border e-commerce is dominated by express delivery, which leads to the failure of sellers to provide customs declaration. Therefore, it is difficult to enjoy the preferential tax policy.

\section{Analysis of the Impact of Cross-Border E-Commerce on China's Foreign Trade Model}

\subsection{Cross-Border E-Commerce Has Changed the Subject of China's Foreign Trade}

With the development of cross-border e-commerce, China's foreign trade operators have been different from before. First, information technology is more widely used in international trade, which leads to the fact that many "virtual enterprises" are established and involved in the world economy and trade. The trade market provides goods or services, thus transforming the traditional way of import and export trade. These "virtual enterprises" form partnerships with trading companies. They strengthen the use of modern information technology to meet various consumer needs to adapt to the change of the external environment. This leads to changes in organizational structure and functions in international trade. Secondly, cross-border e-commerce cooperates with foreign manufacturers and customers through Internet platforms. What's more, the various modes of cross-border e-commerce will optimize the traditional trade modes, and connect manufacturers, importers and exporters at home and abroad as well as foreign customers. Then the traditional trade middleman's position reduces, thus changes the trade main body structure [6].

\subsection{Cross-Border E-Commerce Has Improved Transaction Efficiency}

The traditional trading mode of foreign trade business is backward and inefficient. Moreover, due to the influence of human factors, the error rate is high. Cross-border e-commerce has changed the situation. It realizes the transactions by means of network communication, in the form of chat tools, E-mail and other carriers, which greatly reduces the costs of all parties, such as purchasing cost and transportation cost. In addition, EDI technology can be applied to the design transaction of cross-border e-commerce. It realizes automation in the form of information data. And it reduces manpower operation, and simplifies the process of trade, which as a result improves transaction efficiency.

\subsection{Cross-Border E-Commerce Has Promoted the Development of Flexible Production Methods for Export Enterprises}

Cross-border e-commerce orders generally involve a small amount of money, 
but trades have becoming more frequent. Therefore, each export enterprise needs to strengthen the understanding of and grasp the market demands and changes. In addition, in order to better prevent and control market operation risks, various cross-border e-commerce companies need to control their own transfer costs. They should establish reasonable and realistic business objectives in the first time, and make scientific adjustments to the organization form and production modes of the enterprise. Thus adopt flexible production mode or flexible modularization mode [7].

\subsection{Cross-Border E-Commerce Has Changed the Foreign Trade Enterprise Management Patterns and the Marketing Ways}

The utilization of EDI technology realized the combination with the Internet. It makes the business process more advanced and scientific, effectively transforms the traditional logistics foreign trade enterprise business models. A new management mode integrating information flow, business flow and capital flow has been formed. It significantly reduces the number of middlemen and enables producers and consumers to connect directly. In addition, it also significantly improves the marketing efficiency of traditional e-commerce, reduces marketing costs, makes it easier for customers to buy goods, and effectively improves customers' satisfaction.

\section{Foreign Trade Pattern Transformation Strategies}

\subsection{Improve Laws and Regulations on Cross-Border E-Commerce Enterprises}

Governments should further improve the current laws and regulations for cross-border e-commerce enterprises and establish a hierarchical regulatory system. At the same time, cross-border e-commerce enterprises should constantly improve their technology and improve the existing system to ensure the security of cross-border trading activity information and account funds. Secondly, the existing credit investigation system or system for cross-border e-commerce enterprises should be improved. The credit information of cross-border e-commerce shall be incorporated into the credit information system of the bank. Cross-border e-commerce enterprises should also have the courage to make breakthroughs and innovations, and step up efforts in research and development and product innovation. They also should comprehensively improve their comprehensive competitiveness and effectively integrate the existing resource advantages of enterprises [8].

\subsection{Actively Change the Management Model of Foreign Trade Enterprises}

Managers should attach importance to the role of e-commerce by combining with the background of market economy development. They should also deepen the application levels of e-commerce, and explore overseas markets by combin- 
ing with the actual development of enterprises. To ensure the healthy and long-term development of foreign trade e-commerce, cross-border e-commerce should do a good job in the daily operation and management of enterprises. They should actively improve the science and normativity of management and the ability of information processing and application.

\subsection{Strengthen Security in Transactions among Cross-Border E-Commerce Enterprises}

For cross-border e-commerce enterprises, the real name system can be used to register. Relevant departments could investigate the enterprise's credibility and establish credit files, grasp the credit status of the enterprise and strengthen cooperation with the third party logistics, adopt advanced security technology to ensure the security of mobile transactions, and test the mobile terminal system to ensure the authenticity and reliability of network information [9].

\section{Conclusions}

In recent years, more and more domestic enterprises have entered the cross-border e-commerce market. However, compared with overseas enterprises, China's cross-border e-commerce is still lagging behind due to numerous problems involved. In the following time, the government needs to optimize the business and legal environment, improve the regulatory system, actively guide enterprises to cooperate in building industrial chains, guide enterprises and consumers to actively participate in the market development of cross-border e-commerce, cultivate consumers' consumption habits and maximize the potential of cross-border B2C market in the aim of helping China's foreign trade enterprises in cross-border e-commerce to obtain more profits.

Opportunities and challenges coexist. It has become an irreversible trend that cross-border e-commerce replaces traditional import and export trade. As a developing country, only by rapidly developing cross-border e-commerce can China take the lead in the following trade competition and win the initiative.

\section{Acknowledgements}

Zigong Social Science Joint philosophy and social science research base-Industrial Transformation and Innovation Research Center Project (CYZX2017-03); China Salt Culture Research Center Project (YWHY16-01); Talent introduction and scientific research project launched by Sichuan University of Science and Engineering (2015RC67).

\section{Conflicts of Interest}

The authors declare no conflicts of interest regarding the publication of this paper.

\section{References}

[1] Qin, Z. and Li, S.D. (2002) E-Commerce and International Trade. Posts and Tele- 
com Press, Beijing, 15.

[2] Lu, D.Z. (2010) Discussion on the Impact of E-Commerce on International Trade. Heilongjiang Foreign Trade and Economic Cooperation, Harbin, 3.

[3] http://www.stats.gov.cn/tjsj/tjgb/ndtjgb/qgndtjgb/200902/t20090226_30023.html

[4] http://www.w3.org/WAI/eval/Overview.html

[5] Lu, P. (2013) Discussion on the Impact of E-Commerce on International Trade. China E-Commerce, 18, 10.

[6] Fan, W.J. (2015) The Development of Cross-Border E-Commerce and the Transformation of China's Foreign Trade Model. Foreign Economy and Trade, No. 1, 4-7.

[7] Li, F. (2015) The Development of Cross-Border E-Commerce and the Influence on the Transformation of China's Foreign Trade Model. Leadership, No. 31, 81-83.

[8] Zhao, X.M. and Yang, X. H. (2016) Analysis on the Impact of Cross-Border E-Commerce Development on China's Foreign Trade Model Transformation. Commercial Economic Research, No. 8, 75-77.

[9] W3C.org. (2016) Accessibility Evaluation Resources. 